\title{
Analysis of Personal Loans and Household Financial Health of Primary School Teachers in Kenya
}

\author{
Florence Jepchumba Bett ${ }^{1}$, Robert Kirui ${ }^{2}$ \\ Department of Accounting, Finance \& Management Science, Egerton University, Nakuru, Kenya \\ Email address: \\ bettflo85@gmail.com (F. J. Bett), robertkirui98@gmail.com (R. Kirui)
}

\section{To cite this article:}

Florence Jepchumba Bett, Robert Kirui. Analysis of Personal Loans and Household Financial Health of Primary School Teachers in Kenya. International Journal of Economics, Finance and Management Sciences. Vol. 6, No. 1, 2018, pp. 6-17. doi: 10.11648/j.ijefm.20180601.12

Received: October 24, 2017; Accepted: November 9, 2017; Published: January 11, 2018

\begin{abstract}
Liberalization in the finance industry in Kenya has led to increased access to credit facilities to Kenyan employees. Primary school teachers are among the beneficiaries. The objectives of this study were to: evaluate the effects of school fees loans on household financial health of primary school teachers in Emining division, assess the effects of home improvement loans on household financial health of primary school teachers in Emining division, examine the effects of emergency loans on household financial health of primary school teachers in Emining division and establish the effects of development loans on household financial health of primary school teachers in Emining division. The study used descriptive research design. Purposive sampling was used to collect data from 165 respondents, 5 teachers from each of the thirty three primary schools, in Emining Division, Baringo. Biographic data on the respondents was analyzed using descriptive statistics such as percentages. Primary data for this study was collected using structured questionnaire. The questionnaire was self-administered. Regression was conducted to test the effect of the various independent variables pooled together on the dependent variable. Two tail t-test and ANOVA test was used to determine the degree of significance of the relationship. The data analyzed was presented in form of tables. Relationships between unsecured personal loans and household financial health of primary school teachers in Emining division was determined at alpha level of $p<0.05$. Results of the study showed that there is statistical significant relationship between unsecured personal loans and household financial health. Findings of the study also revealed that there is a strong positive relationship between unsecured personal loans and household financial health with a significance value of $\mathrm{p}=0.000$. Therefore the study concluded that there is strong positive statistical significant relationship between unsecured personal loans and household financial health of primary school teachers in Emining Division, Baringo County, Kenya.
\end{abstract}

Keywords: Household Financial Health, Primary Teachers and Personal Loan

\section{Introduction}

The field of personal or household finance is better reflected in recent years in several research studies. One of the most frequent associations of personal finance is with financial education, the underlying idea being that without adequate knowledge and skills one cannot satisfactorily manage his or her own finances, particularly in a dynamic and complex environment. Besides education, however, other aspects emerge from the literature, which appear to have particular importance in the process of individual financial decision. Individual can either borrow secured or unsecured personal loans. Secured loan is granted to individuals, provided that they deposit some form of security, such as titles, log books or share certificates, [9]. This means that a credit facility is fully secured where collateral used to secure the facility has a value that is sufficient to cover the carrying amount of the loan [9]. Unsecured loan on the other hand is a loan that is issued and supported only by the borrower's credit worthiness rather than a type of collateral. The relative ease and speed at which unsecured personal loans can be obtained have led to increasing number of applications, making it an area of interest in the study of personal finance. This project represents an attempt to establish the effects of unsecured personal loans on household financial health of primary school teachers in Emining Division, Baringo County, Kenya.

A household refers to a person or group of people living in the same compound, answerable to the same family head and sharing a common source of food and income. [21] have 
suggested that consumer financial health is achieved when an individual's day-to-day financial system functions well and increases the likelihood of financial resilience and opportunity. High-quality products and services that help consumers make better financial decisions, retain greater control over their money, and plan for the future, are important tools for achieving financial health. Therefore financial health is a term used to describe one's financial situation. The amount of savings one has, how much he/she is setting away for retirement and how much of his/her income is being spend on fixed or non-discretionary expenses are the dimensions of financial health.

Financial institutions offering unsecured personal loans in Baringo County include Kenya Commercial Bank, Barclays Bank, Co-operative bank, Standard Chartered Bank, Equity Bank, Family Bank and Post Bank. Salaried employees in Baringo County can also access unsecured personal loans from Boresha Sacco, Skyline Sacco and deposit taking Micro finance institutions such as Faulu Kenya and Kenya Women Finance Trust [27]. Emining division has a total population of 278 teachers employed by Teachers Service Commission (TSC) and posted to teach in the 33-mixed day and boarding public primary schools.

Most studies in developing countries [35]; [34] have associated credit especially unsecured personal loans to improved household welfare. However, studies in developed countries [39]; [22] have associated unsecured loans with decreased financial stability. Primary school teachers are among the major beneficiaries of unsecured personal loans due to its flexibility in repayment and ease of access. None of these studies focused on the relationship between unsecured personal loans on house hold financial health of primary school teachers. It is also important to evidence the relationship of unsecured personal loans and household financial health in a developing economic environment. The study sought to determine the relationship between unsecured personal loans on household financial health of primary school teachers.

\section{Literature Review}

This chapter focused on the review of relevant literature and related empirical studies on the effects of unsecured personal loans on household financial health of salaried primary school teachers and other core aspects of the topic under study. The purpose of this review was to identify knowledge gaps which this study sought to fill.

\subsection{Concept of Unsecured Personal Loans}

[46] had a vision of unleashing the productive potential of millions of poverty stricken people. His vehicle to achieve this was unsecured loans. Expanding access to financial services holds the potential to help ease poverty and spur economic development. In practice it has not been so easy. Commercial banks have faced challenges whilst trying to expand access to poor and low- income households in developing economies, [40].
Supporters of unsecured lending argue that access to credit benefits economic development, poverty reduction and the improved of all citizens, [22]. On the other hand, many protest that whilst some consumers are able to manage their borrowing effectively the ease of access to credit causes overindebtedness, [8]. These conflicting opinions have given rise to the discussion about financial health of consumers of unsecured lending.

The impact of unsecured lending especially in the case of personal loans has mixed opinions. Proponents of unsecured lending claim this unprecedented phenomenon is actually a good thing. They believe it improve the economy and provides credit to those who were previously denied access. The poor and previously unbanked are now able to buy the possession they really need and improve their financial position by gaining access to food, healthcare, and jobs. Advocates of unsecured lending exclaim that opportunities have arisen of their customers through this unsecured channel to finance their cars, houses, businesses and extend their education, [4].

[22] suggested that debt "may be a more sensitive barometer of financial well-being than income" because it represents accumulated hardships over time. While this observation reinforces the likely importance of debt as a socio economic indicator, it also points to the potential confounding that arises from longitudinal accumulation of debt.

\subsection{Nature and Types of Unsecured Personal Loans}

There are two major types - revolving line of credit and fixed-interest installment loans. Credit cards, medical bills, and auto, student, and payday loans are categorized as unsecured debt.

There are different types of credit cards, including no annual fee, rewards, low interest, and department store credit cards. They are offered with different perks such as concierge service, insurance policies, extended warranty, free airfare, and hotel stays. Some issuers also feature discounted purchases, flowers, movie tickets, and more. Discounts may not be available for internet purchases. Many credit card issuers offer roadside assistance, including breakdown towing, lock-out assistance, fuel delivery, and flat tire changes. Hazard weather services, emergency accommodation, and car rental are also offered.

The Normal Loan is designed to address the development needs such as Building homes, Large Scale farming, Motor vehicle purchase among others [13]. This is a loan granted mainly for the purpose of long term development. Repayment is spread over a period of 72 months, [25].

The top up or refinance loans allow members to borrow more money to complete projects. These are loans for any additional money which will enable members to complete initiated projects, and boost savings by cash, [7].

The Somesha Loan has been designed to meet all the school fees needs of clients. It is given to clients with existing business in a group set up. It can be a first loan for a client who feels that school fee is the most pressing issue. It can also be given as an additional loan. The money is used to pay tuition and board, textbooks, school supplies, and other 
expenses. This product also extends to other educational courses such driving school, short courses, training etc, [30]. The loan is available to finance all levels of education; Elementary, Primary, High School and College (Graduate \& Post graduate), [2]. It is a loan intended for educational advancement, this loan can be taken out by parents/guardians for students or by salaried individuals who wish to further their studies, [24].

Further Advances for existing borrowers who have conducted their accounts satisfactorily for the last three years or to prospective borrowers holding clean title of residential property in a city, town or municipal centre, are allowed to borrow home improvement loans [2]. This is a loan for Repairs / Renovations / Improvement / Extension of Home and for Furniture, Fittings \& Fixtures, [3] These are loans that give the opportunity to buy own property. Home buyers need to make provision for the upfront bond registration and transfer costs as well as any deposit required. With this product, you can buy an existing, developed residential property and get up to $100 \%$ financing, [10].

Auto financing is another type of personal loan offered by financial institutions and car dealerships. The money can be used to purchase a new or used vehicle. This type of financing is offered to borrowers with good or tarnished credit, but in the latter case collateral is often required.

\subsection{Concept of Household Financial Health}

Household refers to a person or group of people living in the same compound, answerable to the same family head and sharing a common source of food and income.

The World Health Organization (WHO) defines "quality of life" as the "individuals perception of their position in life in the context of the culture and value of systems in which they live and in relation to their goals, expectations, standards and concern", [45]. Financial health lies centrally on overall health. The quality of life assessment instrument developed by the WHO incorporates areas such as physical health, psychological, level of independence, social relationships, environment, spirituality, religion and personal beliefs. Financial aspects fit under the environment category and can be related to the "financial resources" and "freedom" sub-groupings within "environment".

The concept of financial health is a difficult one to describe exactly, although, logically it should be situated in concepts of general health. Many attempts have been made to provide both qualitative and quantitative measures of financial health but there remains little agreement as to the best way to measure the construct, or even which construct was being measured, [39]. They further report that many researchers have shown economic distress to be a good predictor of lower levels of overall health. There is currently a gap in the research as to what exactly is meant by the term financial health and an easy way to think about financial health is the status of being financially healthy, happy and free from worry, [44].

Financial health is a term used to describe the one's personal financial situation. Financial therapy is the integration of cognitive, emotional, behavioral, relational, and economic aspects of financial health, [15] Therefore, financial health compares to the level of satisfaction a person feels about their financial situation. Financial satisfaction includes being content with one's material (objective) and non-material (subjective) financial situation, [23]. How a person manages his or her personal finances has been shown to be a major influence contributing to satisfaction or dissatisfaction with a person's financial situation, [36].

The basic element of financial health is net worth. Financial health can be determined by learning how to prepare various financial statements. Financial statements are documents that accurately reflect one's personal financial position at a specific point in time. These statements include a budget (record of expected income and spending for the future, generally for a month or a year) a balance sheet (record of one's assets, what is owned) and liabilities (what one owe others) at a specific point in time, usually at the end of a month, quarter, or year) and an income statement (record of spending over a specific period of time, generally a month or a year). Net worth can be calculated using a personal balance sheet and financial ratios can be calculated using personal balance sheet and personal income statement, [41].

Financial health is a term used to describe one's financial situation. The amount of savings one has, how much he/she is setting away for retirement and how much of his/her income is being spend on fixed or non-discretionary expenses are the dimensions of financial health. The parameters used to measure household financial health are net worth, liquidity, solvency, savings and debt servicing [17]. Credit scores and credit changes as well as other credit record variables are also used to measure financial health. Credit scores conveniently summarize one's credit history.

Prior research has identified several financial ratio guidelines that are useful in identifying household financial health issues, such as liquidity problems and insolvency [1] [11]; [12]; [29]. Since each ratio could capture a different aspect of the financial circumstances of the household, a single ratio may not be comprehensive enough to accurately capture the magnitude to which households are having financial problems [1]; [29]. Financial ratios could be used to assess a household's ability to avoid major debt (solvency ratio), maintain adequate cash reserves for emergencies (liquidity ratio), and show the accumulation of assets towards financial goals (investment assets ratio).

Two ratios can help in determining whether or not one have enough monetary assets to pay for a large, unexpected expense or to tide an individual over in case of a period of reduced or eliminated income: the current ratio and the "month's living expenses covered" ratio. The current ratio tells how many times over one could pay off his/ her current liabilities with the cash he/ she have on hand. To calculate current ratio, divide the amount monetary assets (your current assets) by the amount of current liabilities. The more times one can pay off his/ her current liabilities, the better off they are financially. A ratio greater than two is recommended. The second important ratio is the "month's living expenses covered" ratio. This ratio 
tells how many months one could survive financially if he/ she lost all current sources of income. To calculate this ratio, divide the amount of monetary assets by the amount of monthly living expenses. Living expenses should not include charitable contributions, taxes, or savings, because if one lost his/ her job, he/ she would not have these expenses or savings. A ratio that allows you to pay your living expenses for three to six months is recommended. The ratio should be equal to at least as many months as it would take to get a new job if one lost his/ her current job, [41].

The debt ratio and the long-term debt coverage ratio can help determining whether or not one can meet his/ her current or long-term debt obligations. Debt ratio tells whether one could pay off all his/ her liabilities if he/ she liquidated all his/ her assets. This ratio is equal to total liabilities divided by total assets and represents the percentage of assets that are financed with borrowed money. This ratio should go down as one grows older. Long-term debt coverage ratio tells how long one could continue to make payments on his/ her long-term debt based on the amount of money he/ she have for living expenses. To calculate this ratio, divide the amount available for living expenses (i.e., wages minus taxes) by the amount of long-term debt payments. The higher this ratio, the better; a higher ratio indicates that one could cover his/ her debt payments for a longer period of time. This ratio should go up over time [41].

The net savings ratio and the gross savings ratio can help in determining whether one is saving as much of his/ her income as he/ she think. Net savings ratio tells what proportion of one's after-tax income he/ she is are saving. To calculate this ratio, divide the amount of income saved by the amount of income used to cover living expenses. In the United States, the average ratio has ranged between negative 2 percent and 8 percent; however, the ratio may vary from this average depending on one's current financial stage and personal goals. If this ratio is decreasing, necessary changes should be made. Gross savings ratio tells what proportion of one's before-tax income is being saved. This ratio is equal to total savings divided by total income, [41].

\subsection{Theoretical Review}

This section focuses on the various theories guiding the study by specifically discussing Fisher Irving, the theory of interest and Modigliani and Friedman Expenditure, savings and Life Cycle theory.

\subsubsection{Fisher Irving, the Theory of Interest}

Theory of interest rates by [16] relates the nominal interest rate $i$ to the rate of inflation $\pi$ and the "real" interest rate $r$. The real interest rate $r$ is the interest rate after adjustment for inflation. It is the interest rate that lenders have to have to be willing to loan out their funds. Fisher states that the rate of interest is dependent upon very unstable influences many of which have their origin deep down in the social fabric and involve considerations not strictly economic. Any causes tending to affect intelligence, foresight, self-control, habits, the longevity of man, family affection, and fashion will have their influence upon the rate of interest.

Fisher's study postulates that loans can either be private or public loans. Private loans can be further classified to consumption or personal loans and productive or business. Consumption or personal loans are loans of individuals for personal purpose rather than those arising out of business relations. Of this, the first class comprises loans contracted because of misfortune or improvidence. It is evident, therefore, that the loans as just described are made by the borrower for the sake of correcting an income stream the time shape of which is unsatisfactory.

\subsubsection{Modigliani and Friedman Expenditure, Savings and the Life Cycle}

The life-cycle hypothesis has been utilized extensively to examine savings and retirement behavior of older persons. This hypothesis begins with the observation that consumption needs and income are often unequal at various points in the life cycle. Younger people tend to have consumption needs that exceed their income. Their needs tend to be mainly for housing and education, and therefore they have little savings. In middle age, earnings generally rise, enabling debts accumulated earlier in life to be paid off and savings to be accumulated. Finally, in retirement, incomes decline and individuals consume out of previously accumulated savings, [31].

Modigliani postulated that decisions on consumption and savings were made by the individual consumers based on anticipated lifetime earnings and consumption, not just on that years need. This hypothesis would explain the almost universal consumption beyond their means by young people not in terms of immaturity but in their high expectations.

Friedman in 1957 presented the permanent Income Hypothesis, which is similar to Modigliani's work. Milton Friedman's PI hypothesis originates from the basic intuition that individuals would wish to smooth consumption and not let it fluctuate with short run fluctuations in income. In fact the model was developed to explain important empirical facts in a unified framework. For example, why is income more volatile than consumption and why is the long run marginal propensity to consume out of income higher than the short run one? To answer these questions Friedman hypothesized that individuals base their consumption on a longer term view of an income measure, perhaps a notion of lifetime wealth or a notion of wealth over a reasonably long horizon. The basic hypothesis posited is that individuals consume a fraction of this permanent income in each period and thus the average propensity to consume would equal the marginal propensity to consume.

\subsection{Empirical Studies}

[34] carried out a study on the effects of unsecured personal loans on household welfare of secondary school teachers in Bungoma County, Kenya. The objectives of the study were to establish the nature of unsecured personal loans offered by commercial banks and to establish the effects of unsecured personal loans on Household welfare of secondary teachers in Bungoma County-Kenya. The conclusion was that the major 
types of unsecured personal loans borrowed by secondary school teachers were Home improvement, Education, loans to provide capital, medical loans and loans to clear other loans and that access and utilization of unsecured personal loans by secondary school teachers in Bungoma County has led to improved healthcare, and better education, female teachers' empowerment, poverty levels reduction, new business startups, improved total household consumption, provision of startup capital for new businesses and development of better housing by secondary school teachers.

[33] studied on whether student debt jeopardize the short-term financial health of U.S households. The study used a survey of consumer finances to determine whether student loans are associated with household net worth. They concluded that median 2009 net worth $(\$ 117,000)$ for households with no outstanding student loan debt is nearly three times higher than for households with outstanding student loan debt $(\$ 42,800)$. With their multivariate statistics, they indicated that households with outstanding student loan debt and a median 2007 net worth of $\$ 128,828$ incurred a loss of about 54 percent of net worth in 2009 compared with households with similar net worth levels but no student loan debt over the same period. The final conclusion of the study was that outstanding student debt may jeopardize the short-run financial health of households.

[42] studied on the impact of micro-credit on selected household welfare attributes: evidence from Sri-Lanka. Both Quantitative and qualitative approach based on recently conducted national level household survey on micro finance in Sri- Lanka were utilized and Pearson correlation method was used to analyze data. The results indicated that on overall, micro-credit has enabled the household to improve their income, assets, housing condition etc; however, the magnitude of impact varies across different income groups. That micro-credit has largely helped the middle and higher income quintiles to increase their level of income, assets and housing, while there is no significant impact on these attributes for the poorest quintile whose impact of Micro- credit is mainly on their consummation level.

[40] carried out a study on the impact of unsecured lending on the financial wellbeing of consumers. A survey was used to gather data which was statistically analyzed by means of descriptive quantitative research strategy and the conclusion of the study was that those who make use of unsecured lending as a means of accessing finance have a better subjective view of their financial wellbeing than those who do not make use of unsecured lending and further that consumers who make use of multiple unsecured loans have an improved outlook with regard to their financial position than those who do not make use of multiple unsecured loans.

[20] researched on the Impact of microfinance on rural poor households' income and vulnerability to poverty: case study of Makueni district, Kenya. The main objective of the research was to analyze the impact of microfinance on household income as well as measure household vulnerability to poverty after access to microfinance. The study was an experimental case of Makueni district where participants in microfinance programmes and non-participant households were studied over time. On integrating time dynamics in the analysis, the results indicate a positive and significant impact of microfinance on household income. The study concluded that there is a role of microfinance on the improvement of household incomes.

[32] assessed the impact of credit constraints on farm household economic welfare in the Hinterland of Kinshasa, Democratic Republic of Congo. The study used cross sectional data collected at household level in Hinterland of Kinshasa, Democratic Republic of Congo and survey was conducted from February to March 2008. Non- parametric method known as the propensity score matching was applied to compute the impact of credit constraints on farm household welfare and the results from descriptive statistics established the existence of high level of credit constraints among farm households in the area of study. The study concluded that the improvement of farm household access to credit result in increasing economic welfare.

[43] wrote a paper on micro-credit and poverty reduction: a case of Bangladesh. The main purpose of this paper was to give an overview about access to micro-credit for rural poor and its impact on their poverty situation and relevant factors related to income of the micro-credit recipients. Data was collected in two phases from the same respondents (April 2009and April 2010) using a face-to-face interview scheduled from a sample of 360 micro-credit recipients. Additionally, another set of 60 non-credit beneficiary respondents was also taken as a control group to compare the consequences of the program. Different statistical tests (chi-square, f-test) were used to analyze the association and extent of contribution within the variables and in order to assess the factors related to income, education and other variables of the borrowers, multiple regression analysis was performed. Major findings revealed that positive impact was found on income, assets endowment, standard of living and poverty reduction. Utilization of credit appeared to be major factor for credit recipients raising income compared to their control group. Conclusion of the paper was that micro-credit tends to be an important factor to have an impact on household income which minimizes the poverty situation to a reasonable extent.

[19] analyzed the effects of student loans on long-term household financial stability. The study estimated linear probability models in which the dependent variable was a binary measure of household financial stability and the observed relationship between student debt and the outcomes of interest was likely to be compounded by unobserved heterogeneity even when all available human capital and occupation controls were included. For the amount of accumulated student debt that exploits time variations in the size of the federal and private student loan programs, they used an instrument based on the observed upward trend in student borrowing since the 1970s when the federal student loan program was in its early stages. The study concluded that holding student debt is likely associated with decreased financial stability, particularly for individuals who accumulate 
debt but do not complete a Bachelor's degree.

[40] conducted a cross- sectional study to study the access to credit and Household Poverty reduction in Rural Vietnam. The objectives of the study were to propose and implement an econometrics framework seeking to overcome the shortcoming of the research methodology in previous studies and to seek to obtain evidence on the impact of credit on household economic welfare in Vietnam. An economics framework was used to analyses the effect of household credit on the economic welfare of households from two household surveys undertaken in 1992/ 1993 and 1997/198 to devise empirical evidence. The conclusion of the study was that household credit contributes positively and significantly to the economic welfare of household in terms of per capital expenditure, per capital food expenditure and per capital non-food expenditure. The study also concluded that credit has greater positive effects on the economical welfare of poor household and find that the age of the household head, the household size, land ownership and saving and the availability of credit at village level are key factors that affect household borrowing.

[28] carried out a research on the Effect of credit on household welfare: the caseof "village bank" model in bomet district, Kenya. The objectives of the study were to establish the difference of incomes of the household who are participants and non- participants in "village bank" credit in Bomet District and to determine the effect of the "village bank" credit on household expenditure in Bomet District. A sample of 125 "village bank" members was selected, out of which 91 had used the credit service and the other 34 had not. Primary data on the selected respondents were collected using a structured interview schedule and secondary data were obtained from the selected "village banks" operating in the study area and relevant government departments in the district. The study used analysis of variance and Heckman's selection model which corrects for selectivity bias in the sample. The results from the study concluded that farm income, off- farm income; distance to market and household assets influences the probability to participate in "village bank" credit. The household income of credit participants was also higher than that of the non-participants. There was a positive relationship between the amount borrowed and household expenditure. Age of the household head, farm income, distance to market and off- farm income also paid a significant role in influencing the well being of a house hold.

[14], studied indebtedness and the household financial health: An examination of the Canadian Debt Service Ratio distribution concluded that debt and asset holdings of households are relatively well matched, the distribution of the Debt Service Ratio is skewed to the right and this skew has increased slightly since 1999. It was a cross-country comparison of the Canadian DSR distribution with the U.S distribution and the analysis also showed that in 2004, the household sector in Canada seemed less vulnerable to macro-economic shocks than U.S households. The study involved calculation of mean, median, variance, skewnes and

\section{Kurtosis.}

Using evidence from British Household Pannel Survey (BHPS), [41] carried out a research on the impact of unsecured debt on financial distress among British households. An ordered-logit model was estimated for 1995 and 2000 using a self- reported indicator of financial distress and the dependent variables. The conclusions of the study were that the main factors causing debt problems are the unsecured debt- income ratio, the level of mortgage income gearing, the level of financial wealth of households, their health, ethnicity and marital status. More households in the youngest age group reported debt repayments were a heavy burden in 2000, while the opposite applies to the oldest age group where a smaller proportion of household, than in 1995 reported debt was a heavy burden. In particular, the study concluded that the increase in indebtedness of the young was the main factor accounting for their greater tendency to report debt problems.

[24] while conducting a research on stress testing household Debt in Korea concluded that a 100-300 bps increase in interest rate could increase distressed household debts household by $81 / 2-17$ percent point and a drop in real estate prices by 10-30 could add another 4 percent point to distressed debt. That household level analysis suggests that most of the increase in debt can be attributed to increased indebtedness of above - median - income and older households and is closely linked to home ownership. Low levels of nonperforming loans and high bank capitalization levels limit systematic financial risk, but potential risks to household balance sheets point to need for vigilance and further strengthening of risk management capacities. Ensuring that the debt payment ability of households at the end of grace period is taken into account when loans are extended would help reduce future vulnerabilities.

[5] studied on payday credit access and household financial health: evidence from consumer credit records. The study employed a large panel dataset of individual credit records, and census data on payday lender store locations, to access the concern. Matched ZIP codes and state lending laws were used to generate plausibly exogenous variation in access to pay day loans and a little to no effect of access was found on consumer's financial health as measured by credit score levels in 2008 and the incidence of substantive score dropped during the recent recession. The analysis also indicated that neighborhood racial composition had little influence on payday lender store locations conditional on income, wealth and demographic characteristics.

[6] studied on payday loan choices and consequences. They matched administrative data from a payday lender nationally representative credit bureau files to examine the choices of payday loan applicants and assess whether payday loans help or harm borrowers. Basing on regression discontinuity estimates, they concluded that the effect of payday borrowing on credit scores and other measures of financial wellbeing are close to zero. 
Intervening variables

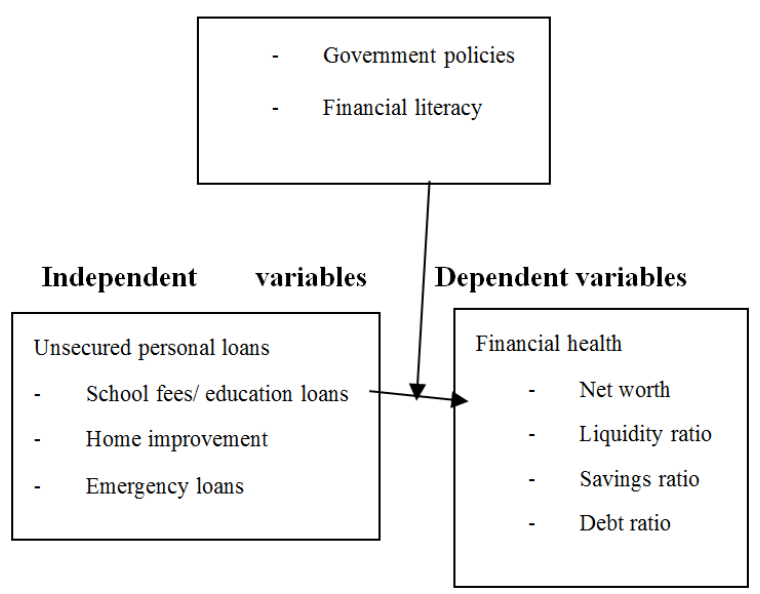

Figure 1. Conceptual Framework.

\section{Methodology}

Descriptive survey research design was used in this study to assess the Effects of Unsecured Personal Loans on household financial health of salaried primary school teachers in Emining Division, Baringo County, Kenya. The rationale for choosing this design is based on its ability to provide information about the naturally occurring status, behavior, attitudes or other characteristics of a particular group and describes what exists and may help to uncover new facts and meaning to depict the participants in an accurate way. The study targeted a population of 6,084 teachers are spread over 676 primary schools. Emining division has a total of population of 278 primary school teachers. The teachers are evenly spread over 32 public primary schools; with only one school having 22 teachers. A sample of 165 was purposively picked. Five teachers in every 33 schools participated in the study. A structured questionnaire was used to collect primary data. Reliability and validity of the study was done through a pilot study in Mogotio division, Baringo County. The pilot data was used to test for reliability using Cronbach Alpha coefficient. A coefficient of 0.70 and above was considered adequate for adoption [30] Primary data was analyzed using regression analysis. The regression model below formed the basis for determining the relationship between unsecured loans and household financial health.

The model is expressed as;

$$
\mathrm{Y}=\alpha 0+\text { bi Xi +bii Xii + biii Xiii + biv Xiv + e }
$$

Where: $\mathrm{Y}=$ Financial Health of Primary School Teachers bi, bii, biii, biv $=$ Coefficients of the independent variables $\mathrm{Xi}=$ School fees loans

$\mathrm{Xii}=$ Home improvement loans

Xiii $=$ Emergency loans

$\mathrm{Xiv}=$ Development loans

$\alpha 0=$ Constant

$\mathrm{e}=$ Error Term

From the regression model the household financial health was measured by observing the effect of a unit increase/ decrease of the independent variables on the household financial health factor. Liquidity ratios, that is, the current ratio and the month's living expenses ratio, savings ratio as well as debt servicing ratios, that is, debt ratio and long term debt coverage ratio was also used to determine household financial strengths or weaknesses of primary school teachers as a result of having taken unsecured personal loans.

\section{Results and Discussion}

The study used multiple regressions model to establish the relationship between school fees loans, home improvement loans, emergency loans and development loans on the household financial health of primary school teachers in Emining Division, Baringo County, Kenya. The regression model was applied as follows:

Table 1. Multiple Regression Analysis for Unsecured Personal Loans and Net worth.

\begin{tabular}{|c|c|c|c|c|c|}
\hline Model & $\mathbf{R}$ & R Square & Adjusted R Square & Std. Error of the Estimate & Durbin-Watson \\
\hline 1 & $.854^{\mathrm{a}}$ & 0.73 & 0.694 & 0.84203 & 1.675 \\
\hline
\end{tabular}

a. Predictors: (Constant), school fees loans, Home improvement loans, emergency loans, Development loans

b. Dependent Variable: Net worth

From Table 1 above, coefficient correlation (R) was $0.854(\mathrm{r}>0.5)$ which means there is a strong positive relationship between unsecured personal loans and house hold financial health of primary school teachers in Emining Division, Baringo County, Kenya. In addition, the coefficient of determination (R2) of 0.730 implies that house hold financial health is explained by $73 \%$ of the variations in unsecured personal loans. From the table, it is evident that there is no autocorrelation because the Durbin-Watson value is 1.675 which is between 1.5 and 2.5 .

Table 2. ANOVA Test of the Relationship between Unsecured Personal Loans and Net worth.

\begin{tabular}{lllllll}
\hline Model & & Sum of Squares & Df & Mean Square & F & Sig. \\
\hline & Regression & 57.472 & 3 & 14.368 & $.000^{\mathrm{b}}$ \\
& Residual & 21.27 & 119 & 0.709 & \\
& Total & 78.743 & 122 & & \\
\hline
\end{tabular}

a. Dependent Variable: Net worth

b. Predictors: (Constant), School fees loans, Home improvement loans, Emergency loans, Development loans

Source: Research Data, (2016) 
From Table 2 above, the level of significance was $p=0.000$ with an F value of 20.265 . This indicates that there is statistical significant relationship between unsecured personal loans and household financial health because P value is less than 0.05 .

Table 3. Regression Coefficients of the Relationship between Unsecured Personal Loans and Net Worth.

\begin{tabular}{|c|c|c|c|c|c|}
\hline \multicolumn{6}{|l|}{ Coefficients $^{\mathrm{a}}$} \\
\hline \multirow[b]{2}{*}{ Model } & \multicolumn{2}{|c|}{ Unstandardized Coefficients } & \multirow{2}{*}{$\begin{array}{l}\text { Standardized Coefficients } \\
\text { Beta }\end{array}$} & \multirow{2}{*}{$\mathbf{T}$} & \multirow[b]{2}{*}{ Sig. } \\
\hline & B & Std. Error & & & \\
\hline (Constant) & 2.344 & 1.487 & & 1.576 & 0.125 \\
\hline School fees loans & -0.745 & 0.22 & -0.465 & -3.393 & 0.002 \\
\hline Home improvement loans & -0.501 & 0.359 & -0.425 & -1.393 & 0.174 \\
\hline Emergency loans & -0.392 & 0.561 & -0.349 & -0.699 & 0.49 \\
\hline Development loans & 1.631 & 0.495 & 1.844 & 3.295 & 0.003 \\
\hline
\end{tabular}

Dependent Variable: Net worth

Source: Research Data, (2016)

Table 3 shows the significance ( $p$ ) values for each independent variable (unsecured personal loans). If $p<0.05$, the conclusion is that the independent variable is a predictor of the dependent variable. In testing the relationship between unsecured personal loans and Household financial health, significance value of (p) of 0.174 and 0.490 which is more than 0.05 shows Home improvement loans and emergency loans does not have statistically significant effect on household financial health.

Table 4. Multiple Regression Analysis for Unsecured personal loans and Liquidity Ratio.

\begin{tabular}{llllll}
\hline Model & R & R Square & Adjusted R Square & Std. Error of the Estimate & Durbin-Watson \\
\hline 1 & $.806^{\mathrm{a}}$ & 0.649 & 0.602 & 0.68804 & 1.512 \\
\hline
\end{tabular}

a. Predictors: (Constant), school fees loans, Home improvement loans, Emergency loans, Development loans

b. Dependent Variable: Liquidity Ratio

Source: Research Data, (2016)

From Table 4 above, coefficient correlation (R) was $0.806(\mathrm{r}>0.5)$ which means there is a strong positive relationship between unsecured personal loans and house hold financial health of primary school teachers in Emining Division, Baringo County, Kenya. In addition, the coefficient of determination (R2) of 0.649 implies that household financial health is explained by $64.9 \%$ of the variations in unsecured personal loans. From the table, it is evident that there is no autocorrelation because the Durbin-Watson value is 1.512 which is between 1.5 and 2.5

Table 5. ANOVA Test of the Relationship between Unsecured Personal Loans and Liquidity Ratio.

\begin{tabular}{llllll}
\hline Model & & Sum of Squares & Df & Mean Square & F \\
\hline & Regression & 26.2822 & 3 & 6.571 & 13.879 \\
& Residual & 14.202 & 119 & 0.473 & $.000^{\mathrm{b}}$ \\
& Total & 40.485 & 122 & & \\
\hline
\end{tabular}

a. Dependent Variable: Liquidity Ratio

b. Predictors: (Constant), School fees loans, Home improvement loans, Emergency loans, Development loans

Source: Research Data, (2016)

From Table 5 above, the level of significance was $p=0.000$ with an $F$ value of 13.879 . This indicates that there is statistical significant relationship between unsecured personal loans and household financial health because $\mathrm{P}$ value is less than 0.05 .

Table 6. Regression Coefficients of the Relationship between Unsecured Personal Loans and Liquidity Ratio.

\begin{tabular}{|c|c|c|c|c|c|}
\hline \multicolumn{6}{|l|}{ Coefficients $^{\mathrm{a}}$} \\
\hline \multirow{2}{*}{ Model } & \multicolumn{2}{|c|}{ Unstandardized Coefficients } & \multirow{2}{*}{$\begin{array}{l}\text { Standardized Coefficients } \\
\text { Beta }\end{array}$} & \multirow{2}{*}{$\mathbf{T}$} & \multirow{2}{*}{ Sig. } \\
\hline & B & Std. Error & & & \\
\hline (Constant) & 9.932 & 1.215 & & 8.173 & 0 \\
\hline School fees loans & -0.99 & 0.179 & -0.862 & -5.52 & 0 \\
\hline Home improvement loans & -0.041 & 0.294 & -0.049 & -0.141 & 0.889 \\
\hline Emergency loans & -0.058 & 0.458 & -0.072 & -0.126 & 0.901 \\
\hline Development loans & 0.126 & 0.404 & 0.199 & 0.312 & 0.758 \\
\hline
\end{tabular}

a. Dependent Variable: Liquidity Ratio

Source: Research Data, (2016)

Table 6 shows the significance $(\mathrm{p})$ values for each independent variable (unsecured personal loans). If $\mathrm{p}<0.05$, the 
conclusion is that the independent variable is a predictor of the dependent variable. In testing the relationship between unsecured personal loans and Household financial health, significance value of (p) of $0.889,0.901$ and 0.758 which is more than 0.05 shows Home improvement loans, emergency loans and development loans does not have statistically significant effect on household financial health.

Table 7. Multiple Regression Analysis for Unsecured personal loans and Debt Ratio.

\begin{tabular}{llllll}
\hline Model & R & R Square & Adjusted R Square & Std. Error of the Estimate & Durbin-Watson \\
\hline 1 & $.661^{\mathrm{a}}$ & 0.437 & 0.362 & 0.05923 & 1.562 \\
\hline
\end{tabular}

a. Predictors: (Constant), school fees loans, Home improvement loans, Emergency loans, Development loans

b. Dependent Variable: Debt Ratio

Source: Research Data, (2016)

From Table 7 above, coefficient correlation $(\mathrm{R})$ was $0.661(\mathrm{r}>0.5)$ which means there is a strong positive relationship between unsecured personal loans and house hold financial health of primary school teachers in Emining Division, Baringo County, Kenya. In addition, the coefficient of determination (R2) of 0.437 implies that house hold financial health is explained by $43.7 \%$ of the variations in unsecured personal loans. From the table, it is evident that there is no autocorrelation because the Durbin-Watson value is 1.562 which is between 1.5 and 2.5

Table 8. ANOVA Test of the Relationship between Unsecured Personal Loans and Debt Ratio.

\begin{tabular}{lllllll}
\hline Model & & Sum of Squares & Df & Mean Square & F & Sig. \\
\hline & Regression & 0.082 & 3 & 0.02 & 5.818 & $.001^{\mathrm{b}}$ \\
& Residual & 0.105 & 119 & 0.004 & & \\
& Total & 0.187 & 122 & & & \\
\hline
\end{tabular}

a. Dependent Variable: Debt Ratio

b. Predictors: (Constant), School fees loans, Home improvement loans, Emergency loans, Development loans

Source: Research Data, (2016)

From Table 8 above, the level of significance was $p=0.001$ with an $F$ value of 5.818 . This indicates that there is statistical significant relationship between unsecured personal loans and household financial health because $\mathrm{P}$ value is less than 0.05 .

Table 9. Regression Coefficients of the Relationship between Unsecured Personal Loans and Debt Ratio.

\begin{tabular}{|c|c|c|c|c|c|}
\hline \multicolumn{6}{|l|}{ Coefficients $^{\mathrm{a}}$} \\
\hline \multirow{2}{*}{ Model } & \multicolumn{2}{|c|}{ Unstandardized Coefficients } & \multirow{2}{*}{$\begin{array}{l}\text { Standardized Coefficients } \\
\text { Beta }\end{array}$} & \multirow{2}{*}{$\mathbf{T}$} & \multirow{2}{*}{ Sig. } \\
\hline & B & Std. Error & & & \\
\hline (Constant) & 0.329 & 0.105 & & 3.146 & 0.004 \\
\hline School fees loans & 0.072 & 0.015 & 0.928 & 4.686 & 0 \\
\hline Home improvement loans & 0.043 & 0.025 & 0.744 & 1.689 & 0.102 \\
\hline Emergency loans & 0.014 & 0.039 & 0.259 & 0.36 & 0.721 \\
\hline Development loans & -0.065 & 0.035 & -1.498 & -1.854 & 0.074 \\
\hline
\end{tabular}

b. Dependent Variable: Debt Ratio

Source: Research Data, (2016)

Table 9 shows the significance ( $\mathrm{p}$ ) values for each independent variable (unsecured personal loans). If $\mathrm{p}<0.05$, the conclusion is that the independent variable is a predictor of the dependent variable. In testing the relationship between unsecured personal loans and Household financial health, significance value of (p) of 0.102, 0.721 and 0.074 which is more than 0.05 shows Home improvement loans, emergency loans and development loans does not have statistically significant effect on household financial health.

Table 10. Multiple Regression Analysis for Unsecured personal loans and savings Ratio.

\begin{tabular}{llllll}
\hline Model & R & R Square & Adjusted R Square & Std. Error of the Estimate & Durbin-Watson \\
\hline 1 & $.804^{\mathrm{a}}$ & 0.646 & 0.599 & 0.12036 & 1.549 \\
\hline
\end{tabular}

a. Predictors: (Constant), school fees loans, Home improvement loans, Emergency loans, Development loans

b. Dependent Variable: Savings Ratio

Source: Research Data, (2016)

From Table 10 above, coefficient correlation (R) was $0.804(\mathrm{r}>0.5)$ which means there is a strong positive relationship between unsecured personal loans and house hold financial health of primary school teachers in Emining Division, Baringo County, Kenya. In addition, the coefficient of determination (R2) of 0.646 implies that house hold financial health is explained 
by $64.6 \%$ of the variations in unsecured personal loans. From the table, it is evident that there is no autocorrelation because the Durbin-Watson value is 1.549 which is between 1.5 and 2.5.

Table 11. ANOVA Test of the Relationship between Unsecured Personal Loans and Savings Ratio.

\begin{tabular}{llllll}
\hline Model & & Sum of Squares & Df & Mean Square & F \\
\hline \multirow{2}{*}{1} & Regression & 0.794 & 3 & 0.199 & 13.709 \\
& Residual & 0.435 & 119 & 0.014 & $.000^{\text {b }}$ \\
& Total & 1.229 & 122 & & \\
\hline
\end{tabular}

a. Dependent Variable: Savings Ratio

b. Predictors: (Constant), School fees loans, Home improvement loans, Emergency loans, Development loans

Source: Research Data, (2016)

From Table 11 above, the level of significance was $p=0.000$ with an $F$ value of 13.709 . This indicates that there is statistical significant relationship between unsecured personal loans and household financial health because $\mathrm{P}$ value is less than 0.05 .

Table 12. Regression Coefficients of the Relationship between Unsecured Personal Loans and Savings Ratio.

\begin{tabular}{|c|c|c|c|c|c|}
\hline \multicolumn{6}{|l|}{ Coefficients $^{\mathrm{a}}$} \\
\hline \multirow{2}{*}{ Model } & \multicolumn{2}{|c|}{ Unstandardized Coefficients } & \multirow{2}{*}{$\begin{array}{l}\text { Standardized Coefficients } \\
\text { Beta }\end{array}$} & \multirow{2}{*}{$\mathbf{T}$} & \multirow{2}{*}{ Sig. } \\
\hline & B & Std. Error & & & \\
\hline (Constant) & 1.651 & 0.213 & & 7.77 & 0 \\
\hline School fees loans & -0.11 & 0.031 & -0.548 & -3.495 & 0.001 \\
\hline Home improvement loans & 0.089 & 0.051 & 0.602 & 1.725 & 0.095 \\
\hline Emergency loans & -0.103 & 0.08 & -0.735 & -1.288 & 0.208 \\
\hline Development loans & -0.009 & 0.071 & -0.085 & -0.133 & 0.895 \\
\hline
\end{tabular}

c. Dependent Variable: Savings Ratio

Source: Research Data, (2016)

Table 12 shows the significance (p) values for each independent variable (unsecured personal loans). If $\mathrm{p}<0.05$, the conclusion is that the independent variable is a predictor of the dependent variable. In testing the relationship between unsecured personal loans and Household financial health, significance value of (p) of $0.095,0.208$ and 0.895 which is more than 0.05 shows Home improvement loans, emergency loans and development loans does not have statistically significant effect on household financial health.

\section{Conclusion}

Unsecured personal loans were studied in terms of school fees loans, home improvement loans, Emergency loans and development loans. The study was guided by four objectives. Based on results from data analysis and findings in relation to the study objectives the following conclusions were made. First, school fees loans have a statistically significant positive effect on household financial health (net worth and debt ratio) and negative effect on liquidity ratio and savings ratio. Second, home improvement loans have a statistically significant positive relationship with all household financial health measures except liquidity. Thus, primary school teachers who borrow home improvement loans experience significant improvement in their household financial health. Third, emergency loans have a statistically significant positive relationship with all household financial health measures except liquidity. This implies that primary school teachers who borrow emergency loans experience significant improvement in their household financial health. Fourthly, development loans have a positive relationship with all household financial health measures that was statistically significant except liquidity. Therefore, it was concluded that unsecured personal loans has statistically significant positive relationship with household financial health.

\section{References}

[1] Baek, E., \& De Vaney, S. A. (2004). Assessing the Baby Boomers' Financial Wellness Using Financial Ratios and a Subjective Measure. Family and Consumer Sciences Research Journal, 32, 321-348.

[2] Bank of Africa (2015) Types of Loans retrieved on Jan 14, 2015 from

http://www.boakenya.com/personal-banking/loans-credit-facil ities/otherloans/unsecured-personalloans

[3] Bank of Baroda (2015) Types of Loans retrieved on Jan 14, 2015 from http://www.bankofbaroda.com/pfs/homeloans.asp

[4] Becchetti L; \& Conzo, P (2013). Credit Access an Life Satisfaction; Evaluating the Non Monetary Effects of Micro Finance. Applied Economics.

[5] Bhutta N. (2012) Payday Credit Access and Household Financial Health; Evidence From Consumer Credit Records.

[6] Bhutta. N; Skiba P. N. \& Tobacman. J. (2014) Payday Loan choices and Consequences.

[7] Boresha Sacco (2015). Types of Loans retrieved on Jan 14, 2015 from https://www.google.com/search?q=boresha+sacco+loans+topu $\mathrm{p} /$ refinaneloans 
[8] Brennan, C., \& Gallagher, K. (2007) Consumer Over Indebtedness a Review of the Quality of Money Advance Services in Scotland. International Journal of Consumer Studies.

[9] CBK (2014) Central Bank of Kenya Prudential Guidelines for Institutions Licensed Under the Banking Act $\mathrm{Cbk} / \mathrm{Pg} / 01$

[10] CFC Stanbic Bank (2014) Types of Loans retrieved on Jan 14, 2015 from http://www.cfcstanbicbank.mobi/heartlandbanking/homeLoan. jsp

[11] Chang, Y. R., Hanna, S., \& Fan, J. X. (1997). Emergency Fund Levels: Is household Behavior Rational? Financial Counseling and Planning, 8(1), 47-55

[12] De Vaney, S. A. (1997). Using Financial Ratios. In Garman, E. T. \& Xiao. J. J. (1997). The Mathematics of Personal Finance: Using Calculators and Computers. 141-153. Houston, TX: Dame Publications, Inc

[13] Drentea, P. \& Lavrakas, P. J, (2000). "Over the Limit: the Association among Health, Race and Debt." Social science and Medicine 50, pp 517-529.

[14] Egerton University Sacco (2014) Types of Loans retrieved on Jan 14, 2015 from http://www.egertonuniversitysacco.coop/index.php/normalloa ns

[15] Farugui U (2008) Indebtedness and the Household Financial Health; An examination of the Canadian Debt Services Ratio Distribution, working paper 2008-46.

[16] Financial Therapy Association (2013) About the FTA, Journal of financial Therapy Article 4, Issue 1.

[17] Friedman. M., (1957), a Theory of consumption function, The Permanent Income Hypothesis, National Bureau of economic Research 0-691-04182-2 (p. 20 - 37), Princeton University Press.

[18] Garrett. S, James. R. N (2013) Financial Ratios and Perceived Household Satisfaction. Journal of financial Therapy, issue 1, vol 4.

[19] Gay, R. (1992). Educational Research: Competencies for analysis and application (4th Ed.). New York: Macmillan Publishing Company. 217-222.

[20] Gichera Thompson. J. (2014) The effects of Student Loans on Long-term Households Financial Stability.

[21] Grades, E. (2007). The impact of Microfinance on Rural Poor Households' Income and Vulnerability to Poverty: Case Study of Makueni District, Kenya. Inaugural- Dissertation.

[22] Gutman. A, Garon. T, Hogarth. J \& Schneider. R (2014), Understanding and Improving Consumer Financial Health in America. Center for Financial Services Innovation found at www.cfsinnovation.com

[23] Hudon M. (2009), Should Access to Credit be a Right? Journal of Business Ethics, 84 (1).

[24] Joo, S., \& Grable, J. E. (2004) an Exploratory Framework of the Determinants of Financial Satisfaction. Journal of family and Economic issues 25(1) 162-171.

[25] Karusulu M. (2008) Stress Testing Household Debt in Korea.
IMF working paper WP/08/255) Asia and Pacific Department.

[26] Kenya Census (2009) Information on Kenya-Census-2009, Retrieved on December, 112015 from http://www.scribd.com/doc/36672705/

[27] Kenya Commercial Bank (2014) Types of Loans retrieved on Jan 14, 2015 from https://ke.kcbbankgroup.com/personal-banking/borrowing/per sonal-loan/detail/unsecurednon-check-off-loan.

[28] Kothari, C. (2008). Research Methodology, Methods and Techniques. New Delhi: New Age Inter-national (p) Limited.

[29] Langat, J. (2009) Effects of Credit on Household Welfare: The Case of "Village Bank" Model in Bomet District Kenya., A Research Project Submitted in Partial Fulfillment of the Requirements for the Award of Master of Science Degree In agriculture and Applied Economics, Egerton University.

[30] Lyons, A. C., \& Yilmazer, T. (2005). Health and Financial Strain: Evidence from the Survey of Consumer Finances. Southern Economic Journal.

[31] Milango Financial services (2014) Types of Loans retrieved on Jan 14, 2015 from

https://www.google.com/search?q=milango+loans\&ie=utf- $8 \&$ oe $=$ utf- 8

[32] Modigliani, Franco and Richard H. Brumberg, (1954), "Utility Analysis and the Consumption Function. An Interpretation of Cross-Section Data.

[33] Mugenda, O. and Mugenda A. (2003) Research Methods: Quantitative and Qualitative Approaches. Nairobi: Acts Press.

[34] Nam. I. \& Elliott., W (2013) Is student Debt Jeopardizing the Short-Term Financial Health of U.S Households?

[35] Nangila, L. O. (2013) The Efects of Unsecured Personal Loans on Household Welfare of Secondary School Teachers in Bungoma County, Kenya., A Research Project Submitted In Partial Fulfillment of The Requirements For The Award Of The Master Degree In Business Administration (MBA), University Of Nairobi.

[36] Orodho, (2009). Elements of Education and Social Science Research Methods.

[37] Porter, N. M \& Garman, E. T. (1993). Testing a Conceptual Model of Financial Well-Being. Financial counseling and planning.

[38] PWC, (2007). Unsecured loans in retail banking. Ensuring sustainability in the Muslim world: Empowering people, leveraging resources. A World Islamic Economic Forum Special Commemorative Publication.

[39] Quach. H., Mullinax. A., \& Murinde V. (2005) Access to Credit and Household Poverty Reduction in Rural Vietam; A Cross-Sectional Study.

[40] Rodrik, Rosenzweig. (2009). Access to Finance Chapter 2, Handbook of Development Economics, Vol. 5.

[41] Sim, J. \& Wright. C. (2000). Research: Concepts, Designs and Methods. Oxford, Oxford University Press.

[42] Steed B. (2011) Personal Finance: Another perspective, Budgeting and Measuring your Financial Health, chapter 3 Brigham Young University. 
[43] Tilakaratna, M. G. (2006) Impact of Micro-Credit on Selected Household Welfare Attributes; Evidence from Sr. Lanka.

[44] World Health organization. (1997) Measuring Quality of Life found at http.//www.who.Int. mental-health/media/68pdf

[45] World Bank Survey, (2012) Unsecured Credit in the Mortgage
Market. World Development Report 2012. Building Institutions for Market. Washington, DC, The World Bank/ Oxford University Press.

[46] Yamane, T. (1967). Statistics, An Introductory Analysis, 2nd Ed., New York: Harper and Row. 